\title{
Analysis of Vibration Effects on Floor of Office Building due to Ground Vibrations from Passing Vehicles
}

\author{
Tuan Norhayati Tuan Chik ${ }^{1, a}$, Shurl Yabi ${ }^{2, b}$, Nor Azizi Yusoff ${ }^{3, c}$, \\ Rachel Alexius Asiew ${ }^{4, d}$, Adzikru Jariman ${ }^{5, e}$ and Mohd. Imran Ghazali ${ }^{6, f}$ \\ 1,2,3,4,5 Department of Structures and Materials Engineering, Faculty of Civil and Environmental \\ Engineering, UniversitiTun Hussein Onn Malaysia, 86400 Johor, MALAYSIA. \\ ${ }^{6}$ Department of Engineering Mechanics, Faculty of Mechanical and Manufacturing Engineering, \\ UniversitiTun Hussein Onn Malaysia, 86400 Johor, MALAYSIA \\ athayati@uthm.edu.my, ${ }^{\text {b}}$ shurl_Y@yahoo.com, ${ }^{\mathrm{c}}$ azizy@uthm.edu.my, ${ }^{\mathrm{d}}$ rachelasiew@gmail.com, \\ eddzdzikru@gmail.com, imran@uthm.edu.my
}

Keywords: Ground borne vibrations, multi-storey, dynamic analysis, vehicles.

\begin{abstract}
Since the earliest days of ground road transportations and constructions in urban areas, there have been complaints of vibration in building caused by this external source of vibration, known as groundborne vibration.Vibration when it exceeds the recommended threshold could affect the structure of the building and any sensitive equipment housed inside the building, as well as causing discomfort and annoyance to the occupants of the building. The objectives of the study are to determine the level of vibration on each floor of a multistorey building due to groundborne vibration from road traffic and to assess the vibration response obtained from both vehicles with the vibration criteria guideline. The selected building for this study is Registrar Office building located in UniversitiTun Hussein Onn Malaysia (UTHM). The scope of study is focused on the effect of groundborne vibration from vehicles on multistorey building and analysing the data using MATLAB and ANSYSv14. The real inputs of vibration from vehicles were measured and obtained using Laser Doppler Vibrometer (LDV). The vibration level from vehicles and footfalls on the multistorey office building can be determined using the Vibration Criteria (VC) guidelines. Finally, from vibration input measured and applied on the floor panel, the vibration level achieved for this Registrar Office building is $99 \%$ above theISO level which exceeds the acceptable vibration limit for office building.
\end{abstract}

\section{Introduction}

Vibration in buildings is a common problem and major concern especially in urban areas because of the daily activities. In major cities, complaints are usually made by annoyed owners of residential homes because of vibrations in buildings that are caused by heavy vehicles passing on adjacent road and construction work nearby due to the distance between buildings and the road, and even between two buildings are close.

Vibration in buildings can reach levels that may not be acceptable to building occupants for one or more reasons such as annoying physical sensations that vibration may produce in the human body, interference with activities such as work, annoying noise caused by rattling of window panes, walls and loose objects and interference with proper operation of sensitive instruments [1].

\section{Sources of Vibration}

There are three major sources of vibration that can affect structures and the sensitive equipment housed inside a building structure [2]. These three major sources are:

i. External sources that include road and rail traffic and constructions activities

ii. Internal activities such as footfalls, service activities (repair works)

iii. Service machinery that include all mechanical and electrical equipment 


\section{Ground-Borne Vibration Induced by Road Traffic}

Hunaidi [2] mentioned that external vibrations induced by road traffic are a common concern worldwide. Vehicles that come with a direct contact with the road surface will induce a dynamic load on the road pavement. The loads will propagate through the soil, where it will reach to the foundation of any nearby building and as a result, this will cause the building to vibrate and will affect the equipment and people that is inside the building. A traffic vibration is characterized by a source-path receiver scenario as shown in Fig.1.

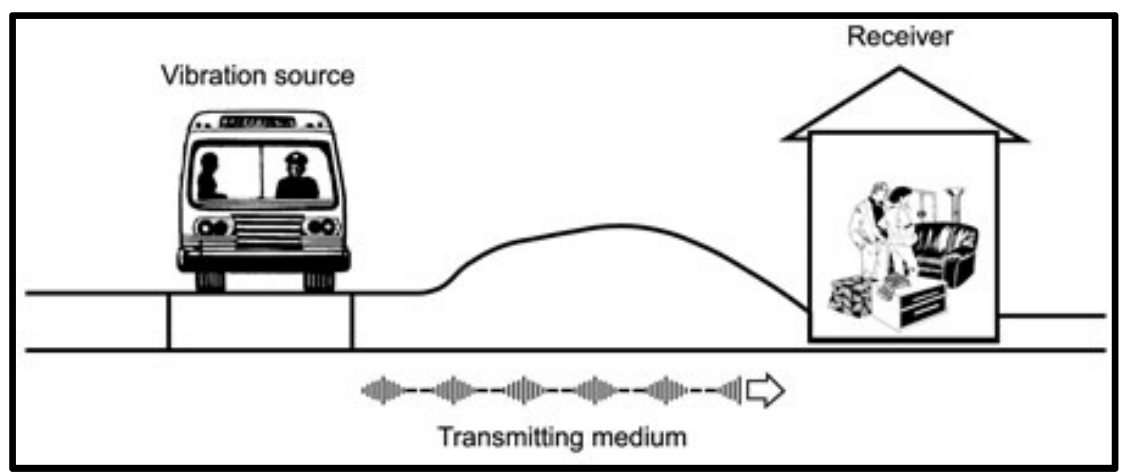

Fig.1 Traffic vibration source-path receiver scenario [2]

Road traffic vibration nuisance in buildings is mainly caused by heavy vehicles that pass at relatively high speed on a road with an uneven surface profile as shown in the Fig.2. Passenger cars and light trucks generate vibrations that are perceptible in buildings.

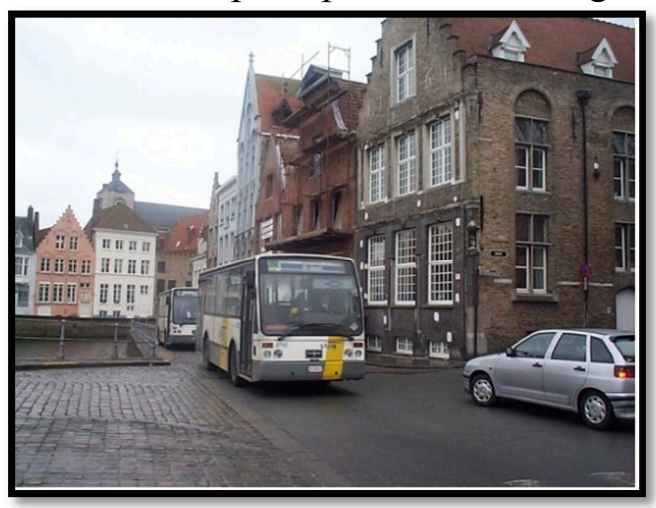

Fig.2 Passage of a bus on a transition between an asphalt surface and paved surface [3]

When vehicles strike on an uneven surface, it will generate an impact load and an oscillating load due to the "axle hop" of the vehicle where ground vibrations are generated and it is predominant at the natural vibration frequencies of the soil. Likewise, the axle hop generates vibrations at the hop frequency. In his conclusion, Hunaidi [2] points that if the natural frequencies of the soil coincide with any of the natural frequencies of the building structures or any of its components, resonance will occur and vibrations will be amplified.

\section{Vibration Criteria (VC) Curve}

In this study, a specific vibration criteria guideline was used in order to investigate and obtain the performance of the structures. The vibration criteria (VC) curves and descriptions were intended to meet the needs of all tools within each category as the previous researchers could judge based on experience mingled with tool-specific specifications [4].

Table 1 shows the application and range of the vibration criteria limits including ISO criteria for human taking into account through experience on past and present projects [5]. 
Table 1Application and range of the vibration criteria curve [5]

\begin{tabular}{|c|c|c|c|}
\hline $\begin{array}{l}\text { Vibration } \\
\text { Curve }\end{array}$ & $\begin{array}{l}\text { Amplitude, } \\
\mu \mathrm{m} / \mathrm{s}\end{array}$ & $\begin{array}{l}\text { Detail } \\
\text { size, } \mu \mathrm{m} / \mathrm{s}\end{array}$ & Application and experience \\
\hline $\begin{array}{l}\text { Workshop } \\
\text { (ISO) }\end{array}$ & 800 & N/A & $\begin{array}{l}\text { Distinctly perceptible vibration. Appropriate to } \\
\text { workshops and no sensitive areas. }\end{array}$ \\
\hline $\begin{array}{l}\text { Office } \\
\text { (ISO) }\end{array}$ & 400 & N/A & $\begin{array}{l}\text { Perceptible vibration. Appropriate to offices and no } \\
\text { sensitive areas. }\end{array}$ \\
\hline $\begin{array}{l}\text { Residential } \\
\text { day (ISO) }\end{array}$ & 200 & 75 & $\begin{array}{l}\text { Barely perceptible vibration. Appropriate to sleep areas in } \\
\text { most instances. Usually adequate for computer } \\
\text { equipment, hospital recovery rooms, semiconductor } \\
\text { probe test equipment and microscopes less than } 40 \mathrm{X}\end{array}$ \\
\hline $\begin{array}{l}\text { Operating } \\
\text { theatre } \\
\text { (ISO) }\end{array}$ & 100 & 25 & $\begin{array}{l}\text { Vibration not perceptible. Suitable in most instances for } \\
\text { surgical suites microscopes to } 100 \mathrm{X} \text { and other equipment } \\
\text { of low sensitivity }\end{array}$ \\
\hline VC-A & 50 & 8 & $\begin{array}{l}\text { Adequate in most instances for optical microscope to } \\
400 \mathrm{X} \text {, microbalances, optical balances, proximity and } \\
\text { projection aligners, etc. }\end{array}$ \\
\hline VC-B & 25 & 3 & $\begin{array}{l}\text { Appropriate for inspection and lithography equipment } \\
\text { (including steppers) to } 3 \mu \mathrm{m} \text { line widths. }\end{array}$ \\
\hline $\mathrm{VC}-\mathrm{C}$ & 12.5 & $1-3$ & $\begin{array}{l}\text { Appropriate standard for optical microscopes to } 1000 \mathrm{X} \text {, } \\
\text { lithography and inspection equipment (including } \\
\text { moderately sensitive electron microscopes) to } 1 \mu \mathrm{m} \text { line } \\
\text { widths. TFT-LCD stepper/scanner processes. }\end{array}$ \\
\hline VC-D & 6.25 & $0.1-0.3$ & $\begin{array}{l}\text { Suitable in most instances for demanding equipment, } \\
\text { including electron microscopes (TEMs and SEMs) and E- } \\
\text { Beam systems. }\end{array}$ \\
\hline VC-E & 3.12 & $<0.1$ & $\begin{array}{l}\text { A difficult criterion to achieve in most instances. } \\
\text { Assumed to be adequate for the most demanding of } \\
\text { sensitive systems including long path, laser-based, small } \\
\text { target systems. E-Beam lithography systems working at } \\
\text { nanometer scales and other systems requiring } \\
\text { extraordinary dynamic stability. }\end{array}$ \\
\hline
\end{tabular}

\section{Field Measurement at Site}

Field measurement was conducted to obtain the signal data for this study by using the Vibrometer equipment. The amplitude of the vibration produced by fully two-axle bus is measured during office hour on working days. Fig. 3(a) shows the Vibrometer equipment used in this study, Laser Doppler Vibrometer (LDV 100) and Fig. 3(b) shows the location of the measurement in the office building, while Fig. 4 shows the side view of the Registrar office building and its layout.

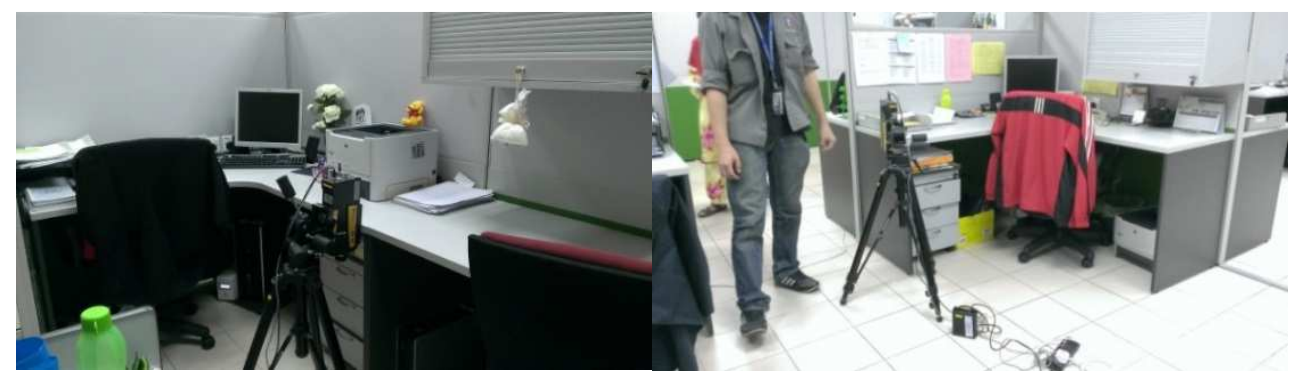

(a) (b)

Fig. 3 (a) Laser Doppler Vibrometer (LDV 100), and (b) Measurement at site 


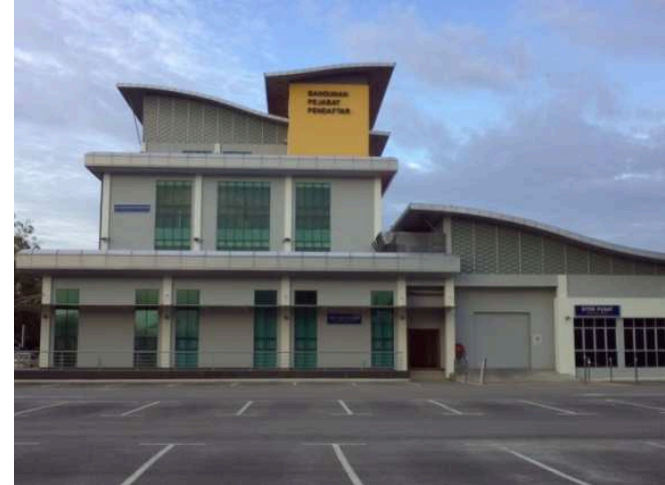

(a)

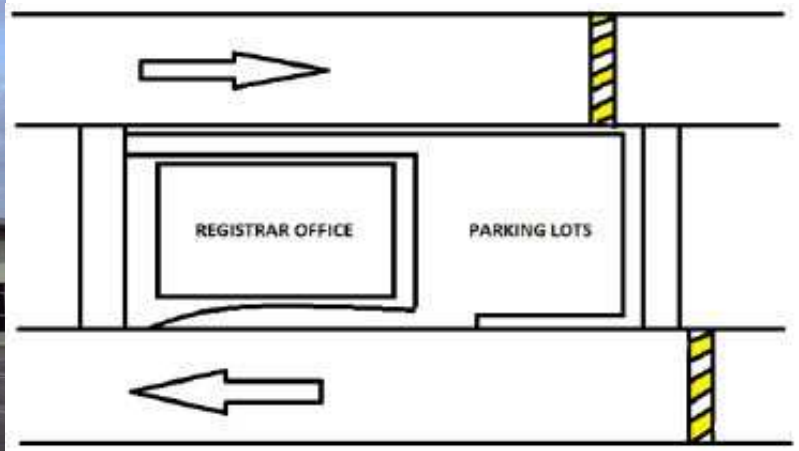

(b)

Fig. 4 (a)Registar office building (side view), and (b) Layout of office building with two main road

\section{Finite Element Modelling (FEM)}

The process of FEM is shown in Fig. 5, and it is applied using the ANSYS and MATLAB software. In this study, the numerical simulation of vibration response on the Registrar office building was carried out by using ANSYS, finite element package software and a tool developed using MATLAB interface and algorithm known as VSATs (Vibration Serviceability Assessment Tools).

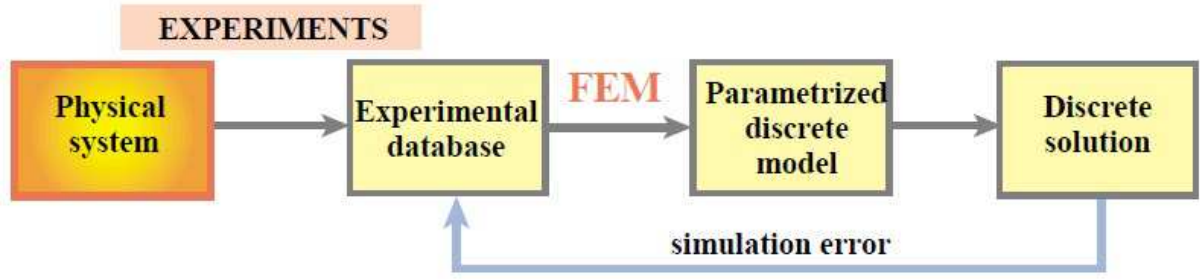

Fig. 5 Finite element method process [6]

All relevant outputs from ANSYS were processed in MATLAB programs, where it will analyse the data from ANSYS and the output produced will be used to determine the level of vibration subjected by the building. Next, the data were compared to the vibration criteria curves which are used as a guideline in this study.

\section{Results and Discussions}

Vibration serviceability analysis was carried out further on each floor using VSATs. Fig. 6 shows the vibration inputs on each floor as well as the vibration response after applying the vibration inputs of vehicles from field measurement while Fig. 6 shows the vibration as well as the vibration response after applying the vibration inputs of vehicles.

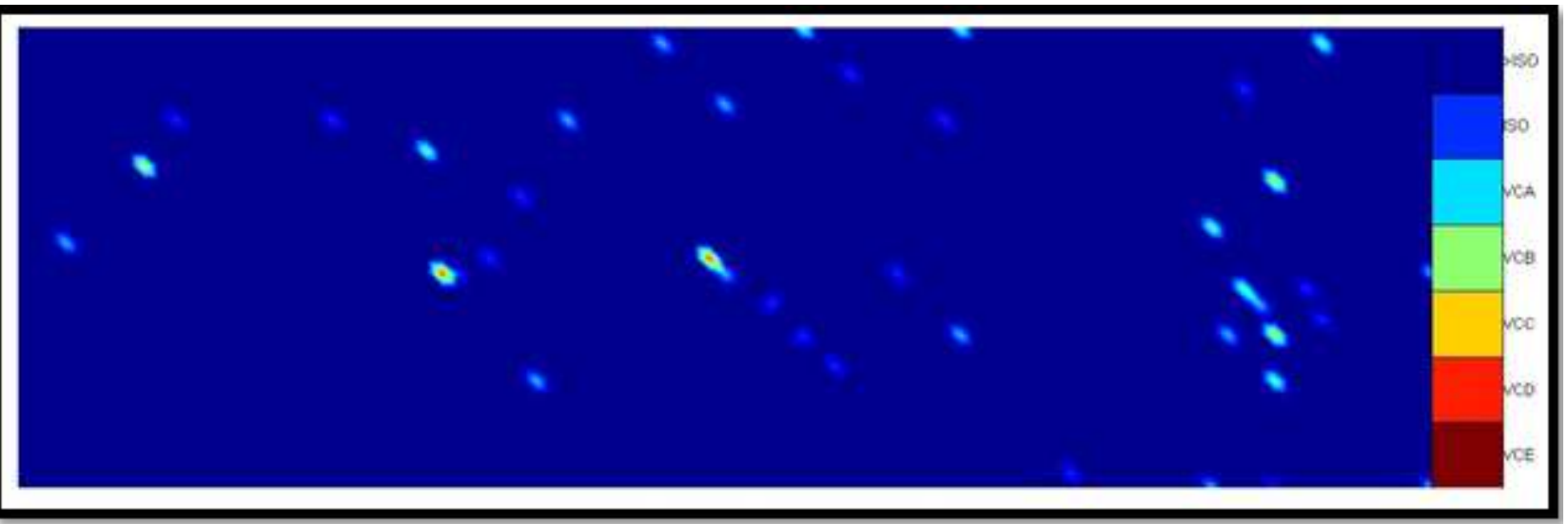

Fig. 6Vibration criteria analysis from vehicles vibration input on floor of the Registrar office building which is at ISO level 
In Fig. 6, the floor vibration criteria response where is above ISO standards at $99 \%$ when referred to the generic criteria guideline [5]. However, the dark blue areas represent the highest VC level which is above ISO standards while the light blue areas represent the ISO standard VC level, appropriate for office and no sensitive areas. Thus, both the dark and light blue areas are unsuitable for sensitive equipment.

\section{Conclusion}

The average value for the vibration criteria of the Registrar office floors when the vehicles vibration inputs from passing vehicle is applied on the floor panel of the Registrar Office building is above ISO level with the percentage of $99 \%$.

Referring to table 2, the maximum value of amplitude for ISO level is $800 \mu \mathrm{m} / \mathrm{s}$, appropriate for office building with no sensitive equipment. Whereas, the maximum value of amplitude for above ISO level is more than $800 \mu \mathrm{m} / \mathrm{s}$ for workshop. Therefore, the maximum value is not acceptable. This means that the vibration incurred by the building from vehicles may have an impact on the building structures, occupants and equipment housed in the office building.

\section{References}

[1] The Railway Association of Canada, Guidelines for New Development in Proximity to Railway Operations. J.E. Coulter Associates Limited. Ontario, Canada (2013) 86- 87.

[2] Hunaidi, O., Traffic vibrations in building, Canadian Journal of Civil Engineering 39(2000) 16.

[3] Lombaert, G. \& Degrande, G., Study of determining factors for traffic induced vibrations in buildings. DWTC Research Programme Sustainable Mobility Research Project MD/01/040. KasteelparkArenberg: KatholiekeUniverstiteit Leuven, 2001.

[4] Amick, H., On generic vibration criteria for advanced technology facilities: with a tutorial on vibration data representation, Journal the Institute of Environmental Sciences, Vol. XL (1997) $35-44$.

[5] Amick, C. H. Gendreau, M. Busch, T. \& Gordon, C. G. Evolving Criteria For Research Facilities: I-Vibration, SPIE Conference 5933: Buildings for Nanoscale Research and Beyond, San Diego, California (2005).

[6] Felippa, C.A., Introduction to finite element methods. University of Colorado, Boulder, United States, 2004. 